Please quote as: Söllner, M. \& Leimeister, J. M. (2012): Opening up the Black Box: The Importance of Different Kinds of Trust in Recommender System Usage. In: 72nd Academy of Management Annual Meeting, Boston, Mass., USA. 


\title{
Opening up the Black Box - The Importance of Different Kinds of Trust in Recommender
}

\author{
System Usage
}

\begin{abstract}
Researchers have shown the importance of trust in numerous domains such as e-commerce, technology acceptance, strategic alliances, and virtual teams. They emphasize the importance of creating insights on trust building for deriving effective design implications for technical systems or organizations. Until now, most researchers have viewed trust as a single construct and did not separately study the trust relationships between different stakeholders in a single study. We argue that the trust relationships between different stakeholders need to be studied separately in order to derive more precise and effective design implications. Thus, this paper aims at opening up the trust black box, and identifying the importance of different trust relationships a user is engaged in when using a recommender system. To achieve this, we address two research questions: a) What are the different trust relationships existent when using a recommender system? and b) How important are the different trust relationships regarding a user's intention to use a recommender system in the future? To answer these research questions, we first build upon trust networks for the Human Computer Interaction community to identify the different trust relationships existent in recommender system usage, after which we use a laboratory experiment to gather empirical insights on the importance of the different trust relationships. The results of the laboratory experiment show that the users' trust in the system itself and in the designers of the system both have the a high impact on users' perceived usefulness and their intention to use the recommender system in the future. To the best of our knowledge, this study is the first to investigate the importance of different trust relationships prevalent in recommender system usage, and to introduce trust networks to trust research in management and IS research.
\end{abstract}


Keywords: trust, trust networks, laboratory experiment, trust in different stakeholders, recommender systems.

\section{REFERENCES}

Abdul-Rahman, A. \& Hailes, S. 2000. Supporting Trust in Virtual Communities. Paper presented at the 33rd Hawai'i International Conference on System Sciences (HICSS 33), Maui, Hawai'i.

Albers, S. 2010. PLS and Success Factor Studies in Marketing. In V. Esposito Vinzi \& W. W. Chin \& J. Henseler \& H. Wang (Eds.), Handbook of Partial Least Squares. Concepts, Methods, and Applications in Marketing and Related Areas.: 409-425. Berlin: Springer.

Ansari, A., Essegaier, S., \& Kohli, R. 2000. Internet Recommendation Systems. Journal of Marketing Research (JMR), 37(3): 363-375.

Baier, A. 1986. Trust and antitrust. Ethics, 96: 231-260.

Bart, Y., Shankar, V., Sultan, F., \& Urban, G. L. 2005. Are the Drivers and Role of Online Trust the Same for All Web Sites and Consumers? Journal of Marketing, 69(4): 133-152.

Benbasat, I., Gefen, D., \& Pavlou, P. A. 2008. Special Issue: Trust in Online Environments. Journal of Management Information Systems, 24(4): 5-11.

Benbasat, I., Gefen, D., \& Pavlou, P. A. 2010. Introduction to the Special Issue on Novel Perspectives on Trust in Information Systems. MIS Quarterly, 34(2): 367-371.

Bhattacherjee, A. \& Sanford, C. 2006. Influence Processes For Information Technology Acceptance: An Elaboration Likelihood Model. MIS Quarterly, 30(4): 805-825.

Cenfetelli, R. T. \& Bassellier, G. 2009. Interpretation of Formative Measurement in Informations Systems Research. MIS Quarterly, 33(4): 689-707.

Chin, W. W. 1998. The Partial Least Squares Approach to Structural Equation Modeling. In G. A. Marcoulides (Ed.), Modern Methods For Business Research. London: LEA.

Chin, W. W. \& Newsted, P. R. 1999. Structural Equation Modeling Analysis with Small Samples Using Partial Least Squares. In R. H. Hoyle (Ed.), Statistical Strategies For Small Sample Research: 308341. Thousand Oaks: Sage.

Corritore, C. L., Kracher, B., \& Wiedenbeck, S. 2003. Editorial. International Journal of Human-Computer Studies, 58(6): 633-635.

Cyr, D., Head, M., Larios, H., \& Bing, P. 2009. Exploring Human Images in Website Design: A MultiMethod Approach. MIS Quarterly, 33(3): 539-A539. 
Davis, F. D. 1989. Perceived Usefulness, Perceived Ease of Use, and User Acceptance of Information Technology. MIS Quarterly, 13(3): 319-340.

Diamantopoulos, A. \& Siguaw, J. A. 2006. Formative Versus Reflective Indicators in Organizational Measure Development: A Comparison and Empirical Illustration. British Journal of Management, 17(4): 263-282.

Ebert, T. A. E. 2009. Facets of Trust in Relationships - A Literature Synthesis of Highly Ranked Trust Articles. Journal of Business Market Management, 3(1): 65-84.

Forrester Research. 2009. North American Technographics Media and Marketing Online Survey: Forrester Research, Inc.

Garfinkel, H. 1963. A Conception of, and Experiments with, "Trust" as a Condition of Stable Concerted Actions. In O. J. Harvey (Ed.), Motivation and Social Interaction: Cognitive Determinants: 187238. New York.

Gefen, D., Karahanna, E., \& Straub, D. W. 2003. Trust and TAM in Online Shopping: An Integrated Model. MIS Quarterly, 27(1): 51-90.

Gefen, D. \& Straub, D. W. 2004. Consumer trust in B2C e-Commerce and the importance of social presence: experiments in e-Products and e-Services. Omega, 32(6): 407-424.

Gefen, D., Benbasat, I., \& Pavlou, P. A. 2008. A Research Agenda for Trust in Online Environments. Journal of Management Information Systems, 24: 275-286.

Gregor, S. 2006. The Nature of Theory in Information Systems. MIS Quarterly, 30(3): 611-642.

Jarvenpaa, S. L., Shaw, T. R., \& Staples, D. S. 2004. Toward Contextualized Theories of Trust: The Role of Trust in Global Virtual Teams. Information Systems Research, 15(3): 250-264.

Jarvis, C. B., Mackenzie, S. B., \& Podsakoff, P. M. 2003. A Critical Review of Construct Indicators and Measurement Model Misspecification in Marketing and Consumer Research. Journal of Consumer Research, 30(2): 199-218.

Kamis, A., Koufaris, M., \& Stern, T. 2008. Using an Attribute-Based Decision Support System For UserCustomized Products Online: An Experimental Investigation. MIS Quarterly, 32(1): 159-177.

Lee, J. D. \& See, K. A. 2004. Trust in Automation: Designing for Appropriate Reliance. Human Factors, 46(1): 50-80.

Leimeister, J. M., Ebner, W., \& Krcmar, H. 2005. Design, Implementation, and Evaluation of TrustSupporting Components in Virtual Communities for Patients. Journal of Management Information Systems, 21(4): 101-135.

Lewicki, R. J. \& Bunker, B. B. 1996. Developing and maintaining trust in work relationships. In R. M. Kramer \& T. R. Tyler (Eds.), Trust in organizations: Frontiers of theory and research: 114-139. Thousand Oaks: Sage. 
Lewis, J. D. \& Weigert, A. 1985. Trust as a Social Reality. Social Forces, 63: 967-985.

Mayer, R. C., Davis, J. H., \& Schoorman, F. D. 1995. An Integrative Model of Organizational Trust. Academy of Management Review, 20(3): 709-734.

Mayer, R. C. \& Davis, J. H. 1999. The Effect of the Performance Appraisal System on Trust for Management: A Field Quasi-Experiment. Journal of Applied Psychology, 84(1): 123-136.

McKnight, D. H., Choudhury, V., \& Kacmar, C. 2002. Developing and Validating Trust Measures for eCommerce: An Integrative Typology. Information Systems Research, 13(3): 334-359.

Muir, B. M. 1994. Trust in automation: Part I. Ergonomics, 37(11): 1905 - 1922.

Nass, C., Steuer, J., \& Tauber, E. R. 1994. Computers are social actors, Proceedings of the Conference on Human factors in computing systems (CHI): 72-78. Boston, Massachusetts, United States: ACM.

Nass, C., Moon, Y., Fogg, B. J., Reeves, B., \& Dryer, D. C. 1995. Can computer personalities be human personalities? International Journal of Human-Computer Studies, 43(2): 223-239.

Nass, C., Fogg, B. J., \& Moon, Y. 1996. Can computers be teammates? International Journal of HumanComputer Studies, 45(6): 669-678.

Nielsen. 2009. Consumer Confidence Survey: The Nielson Company.

Petter, S., Straub, D., \& Rai, A. 2007. Specifying Formative Constructs in Information Systems Research. MIS Quarterly, 31: 623-656.

Podsakoff, P. M., Mackenzie, S. B., Jeong-Yeon, L., \& Podsakoff, N. P. 2003. Common Method Biases in Behavioral Research: A Critical Review of the Literature and Recommended Remedies. Journal of Applied Psychology, 88(5): 879.

Reeves, B. \& Nass, C. 1996. The media equation: how people treat computers, television, and the new media like real people and places. Stanford, CA: Cambridge University Press.

Reichheld, F. F. \& Schefter, P. 2000. E-Loyalty: Your Secret Weapon on the Web. Harvard Business Review, 78(4): 105-113.

Resnick, P., Zeckhauser, R., Swanson, J., \& Lockwood, K. 2006. The value of reputation on eBay: A controlled experiment. Experimental Economics, 9(2): 79-101.

Ringle, C. M., Wende, S., \& Will, A. 2005. SmartPLS 2.0. Hamburg.

Robson, M. J., Katsikeas, C. S., \& Bello, D. C. 2008. Drivers and Performance Outcomes of Trust in International Strategic Alliances: The Role of Organizational Complexity. Organization Science, 19(4): 647-665.

Rousseau, D. M., Sitkin, S. B., Burt, R. S., \& Camerer, C. 1998. Not so different at all: A cross disziplinary view of trust. Academy of Management Review, 23(3): 393-404. 
Sarstedt, M. \& Schloderer, M. P. 2010. Developing a measurement approach for reputation of non-profit organizations. International Journal of Nonprofit and Voluntary Sector Marketing.

Shapiro, S. P. 1987. The Social Control of Impersonal Trust. American Journal of Sociology, 93(3): 623. Sharma, R., Yetton, P., \& Crawford, J. 2009. Estimating the Effect of Common Method Variance: The Method-Method Pair Technique with an Illustration from TAM Research. MIS Quarterly, 33(3): 473-A413.

Singh, J. \& Sirdeshmukh, D. 2000. Agency and trust mechanisms in consumer satisfaction and loyalty judgments. Journal of the Academy of Marketing Science, 28(1): 150-167.

Söllner, M., Hoffmann, A., Hirdes, E. M., Rudakova, L., Leimeister, S., \& Leimeister, J. M. 2010. Towards a Formative Measurement Model for Trust. In H.-D. Zimmermann \& N. Wickramasinghe \& A. Pucihar \& J. Gricar \& M. Babnik (Eds.), 23rd Bled eConference: 65-79. Bled, Slowenia.

Söllner, M. \& Leimeister, J. M. 2010. Did they all get it wrong? Towards a better measurement model of trust, Academy of Management Annual Meeting 2010. Montréal, Canada.

Söllner, M., Hoffmann, A., Hoffmann, H., \& Leimeister, J. M. 2011. Towards a Theory of Explanation and Prediction for the Formation of Trust in IT Artifacts, SIGHCI 2011 Proceedings. Paper 6.

Söllner, M., Hoffmann, A., Hoffmann, H., \& Leimeister, J. M. 2012. Vertrauensunterstützung für soziotechnische ubiquitäre Systeme. Zeitschrift für Betriebswirtschaft: accepted for publication.

Wang, W. \& Benbasat, I. 2005. Trust in and Adoption of Online Recommendation Agents. Journal of the Association for Information Systems, 6(3): 72-101.

Wang, W. \& Benbasat, I. 2008. Attributions of Trust in Decision Support Technologies: A Study of Recommendation Agents for E-Commerce. Journal of Management Information Systems, 24(4): 249-273.

Wang, W. \& Benbasat, I. 2009. Interactive Decision Aids For Consumer Decision Making In E-Commerce: The Influence Of Perceived Strategy Restrictiveness. MIS Quarterly, 33(2): 293-320.

Zucker, L. G. 1986. Production of Trust: Institutional Sources of Economic Structure, 1840 - 1920.

Research in Organizational Behavior, 8: 53. 